\title{
The Association Between the Testis Microbiota and Male Infertility
}

\author{
Testis Mikrobiyotasının Erkek Infertilitesi ile İlişkisi
}

\author{
Ayşe Altun ${ }^{1}$ (D), Sibel Bulgurcuoğlu Kuran² (D), ilknur Keskin³ ${ }^{3}$, Ateş Kadıoğlu ${ }^{4}$ \\ 'Department of Obstetrics and Gynaecology, Faculty of Medicine, Istanbul University, Turkey \\ 2Department of Obstetrics and Gynaecology, Faculty of Medicine, Istanbul University, Turkey \\ ${ }^{3}$ Department of Histology and Embryology, Medical Faculty, Istanbul Medipol University, Istanbul, Turkey \\ ${ }^{4}$ Department of Urology, School of Medicine, Istanbul University, Turkey
}

ORCID ID: A.A. 0000-0002-2765-5766; S.B.K. 0000-0003-4267-2158; I.K. 0000-0002-7059-1884; A.K. 0000-0002-4239-7638

Cite this article as: Altun A, Bulgurcuoğlu Kuran S, Keskin I, Kadığlu A. The association between the testis microbiota and male infertility. Experimed 2021; 11(2): 140-2.

\begin{abstract}
In recent years, substantial findings have been reported about the effects of microbiota on human health. In our study, we aimed to compare the outcomes of microbiota assays of testicular tissue obtained by testicular sperm extraction (TESE) from 2 patients with male infertility. In the first patient who had azoospermia, Illumina sequencing detected the following bacterial flora in the collected tissue homogenates: Firmicutes (53\%), Bacteroidetes (12\%), Actinobacteria (12\%), Proteobacteria (8\%), Fusobacteria (8\%), SR1 (7\%), TM7-3 (3\%) and OD-1 (1\%). In the second patient who had oligozoospermia, Firmicutes (13\%), Bacteroidetes (15\%), Actinobacteria (7\%) and Proteobacteria (64\%) were detected in the testicular tissue. Our preliminary study confirmed that certain types of bacteria exist in testicular tissues of infertile men. Future studies with more infertile and healthy men are required to understand the importance of these microorganisms in the pathophysiology of male infertility.
\end{abstract}

Keywords: Testicular tissue, microbiota, male infertility

\section{INTRODUCTION}

The microbiota is a microorganism community operating in various parts of the human body (1). The bacterial microbiome (BM) has been described as an extracellular microenvironmental component (2). In recent years, much information has been collected about the effects of the microbiota on human health. Specifically, Alfano et al. (3) proved that the human testicle is not sterile and showed the content of microbiota in the testicular tissue. Another translational study revealed that intestinal microbiota could öz

Son yıllarda mikrobiyotanın insan sağlığı üzerindeki etkileri hakkında önemli bulgular rapor edilmiştir. Çalışmamızda erkek infertilitesi olan 2 hastadan testiküler sperm ekstraksiyonu (TESE) ile elde edilen testis dokusunun mikrobiyota analizinin sonuçlarını karşılaştırmayı amaçladık. Azospermik olan ilk hastada, toplanan doku homojenatlarında Illumina dizilemesi ile şu bakteri florasına saptandı: Firmicutes (\%53), Bacteroidetes (\%12), Actinobacteria (\%12), Proteobacteria (\%8), Fusobacteria (\%8), SR1 (\%7), TM7-3 (\%3) ve OD-1 (\%1). Oligozoospermi olan ikinci hastanın ise testis dokusunda Firmicutes (\%13), Bacteroidetes (\%15), Actinobacteria (\%7) ve Proteobacteria (\%64) bakterileri saptandı. Ön çalışmamızda, infertil erkeklerin testis dokusunda belirli bakteri türlerinin bulunduğu doğrulandı. Erkek infertilitesinin patofizyolojisinde bu mikroorganizmaların önemini anlamak için infertil ve sağlıklı erkeklerle yapılacak ileri çalışmalara ihtiyaç vardır.

Anahtar Kelimeler: Testiküler doku, mikrobiyota, erkek infertilitesi

have an impact on sex hormone levels and consequently affect spermatogenesis (4).

In this preliminary study, we aimed to compare the outcomes of microbiota assays of testicular tissues obtained by testicular sperm extraction (TESE) from 2 infertile men (one with azoospermia and the other with oligozoospermia).

\section{CASE REPORT}

This study was approved by the Research Ethics Committee of Istanbul Medipol University on June 23, 2020 
(E-10840098-604.01.01-6176). Both patients provided their written informed consent. After TESE surgery, testicular tissues were homogenized and stored at $-80^{\circ} \mathrm{C}$. Bacterial genes were obtained using $16 \mathrm{~S}$ rRNA primers according to a DNA isolation kit protocol (Isolation kits for QuickGene, U.S.A). Then, bacterial variations and quantities were evaluated $(5,6)$ using next-generation sequencing. Bacterial variations were distinguished through bioinformatics.

\section{Case- 1 and result}

The first patient was a 34-year-old azoospermic man and TESE was performed twice for 2 in vitro fertilization (IVF) procedures. Serum Follicle-stimulating hormone (FSH), Luteinizing hormone (LH) and testosterone levels were normal, and the patient had $46 \mathrm{XY}$ chromosomes with a normal karyotype. There was no microdeletion according to $Y$ chromosome scanning. Only a low sperm count could be obtained from the patient by TESE and a small amount of the testicular tissue was used in microbiota analysis. The following bacteria were detected in the tissue by Illumina analysis: Firmicutes (53\%), Bacteroidetes (12\%), Actinobacteria (12\%), Proteobacteria (8\%), Fusobacteria (8\%), SR1 (7\%), TM7-3 (3\%) and OD-1 (1\%) (Figure 1).



Figure 1. The precense of bacteria in the TESE microbiota of first patient.

\section{Case- 2 and result}

The second patient was a 32-year-old man whose sperm concentration was 13 million/ml (total motility was $45 \%$ and sperm morphology was 6\%). Testicular sperm cells were required for recurrent IVF failure. Serum FSH, LH and testosterone levels were normal, and the patient had $46 \mathrm{XY}$ chromosomes and a normal karyotype. There was no microdeletion in the genetic scanning of the $\mathrm{Y}$ chromosome. Illumina testing revealed Firmicutes (13\%), Bacteroidetes (15\%), Actinobacteria (7\%) and Proteobacteria (64\%) (Figure 2).

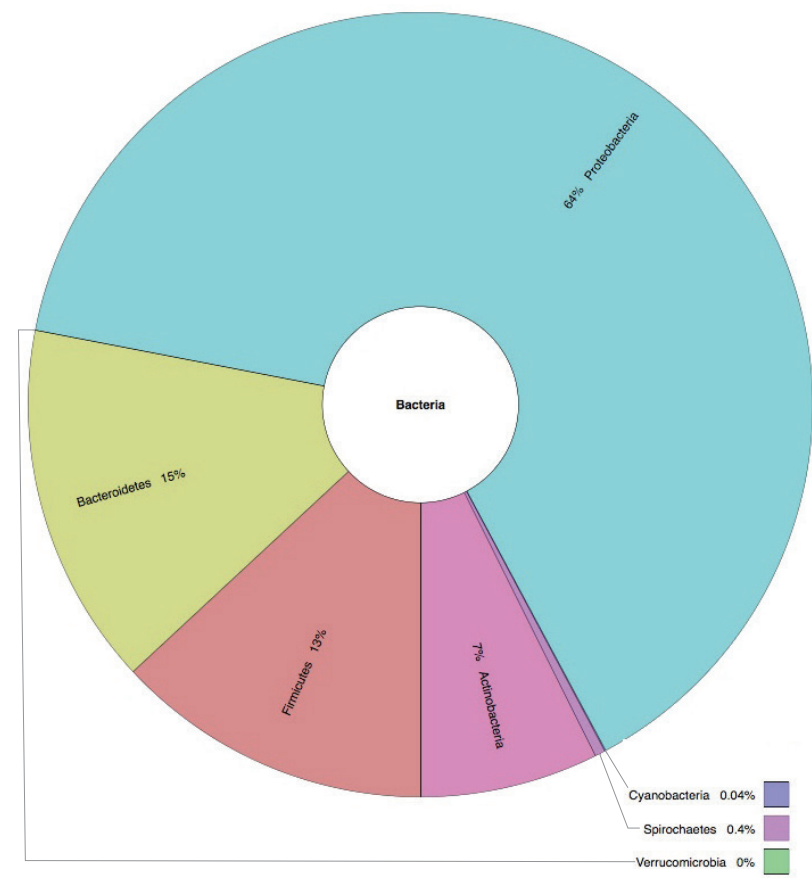

Figure 2. The precense of bacteria in the TESE microbiota of second patient.

\section{CONCLUSION}

Sperm parameters are claimed to be affected by genetic and environmental factors (7). Sperm production occurs in the testes from spermatagonia in seminiferous tubules where Sertoli cells also provide structural and immunological support $(8,9)$. Spermatogenesis is claimed to be affected by the extracellular microenvironment as well (10). The testicular microbiome was initially demonstrated by Alfano et al in azoospermic men (3). This pivotal study showed that human testicles are not sterile and presented new findings about the testicular microbiome. However, the variety of the microorganisms in healthy, neoplastic and non-functioning testes (i.e., in infertile cases) has not been identified yet. Within this first time context, our results involved comparative analyses that were obtained from men with azoospermia and oligozoospermia, which revealed some differences in the distribution of the microorganisms.

In our pilot study, Actinobacteria, Bacteroidetes, Firmicutes and Proteobacteria were characterized as the dominant phyla. The involvement of Firmicutes, Bacteroidetes, Actinobacteria, Proteobacteria, Fusobacteria, SR1, TM7-3 and OD-1 bacteria in the azoospermic patient showed differences in the manner of variation. The Clostridia class of Firmicutes has been associated with sperm motility (11) and morphology (12). Thus, it can be associated with impaired sperm production. Proteobacteria, on the other hand, constituted the majority of the microorganisms in the oligozoospermic patient, suggesting that this class of bacteria may be a member of testicular flora in fertile male population. These findings may contribute to revealing 
the role of microbiomes on male infertility. Future studies with more infertile and healthy men are required to understand the importance of these microorganisms in the pathophysiology of male infertility.

Acknowledgments: The authors would like to thank all participants and research assistants for their effort in soliciting cases and controls and conducting interviews.

Ethics Committee Approval: This study was approved by the Research Ethics Committee of Istanbul Medipol University on June 23, 2020 (E10840098-604.01.01-6176). The two men in the study were given oral and written information about the study and ample time to consider their participation; both gave written consent. Furthermore, both men were informed about possible publication and gave written consent for their cases to be published.

Peer-review: Externally peer-reviewed.

Author Contributions: Conception/Design of Study - A.A., S.B.K., I.K., A.K.; Data Collection - A.A., S.B.K., İ.K., A.K.; Analysis and/or Interpretation - A.A., S.B.K., I.K., A.K.; Drafting Manuscript - A.A., S.B.K., I..K., A.K.; Final Approval and Accountability - A.A., S.B.K., I.K., A.K.

Conflict of Interest: The authors have no conflict of interest to declare.

Financial Disclosure: The financial part of our study was provided by our own budget and was supported by Diagen Biotechnological Systems.

Teşekkür: Yazarlar tüm katılımcılara ve araştırma görevlilerine vakaları ve kontrolleri talep etme ve görüşme yapma çabalarından dolayı teşekkür eder.

Etik Komite Onayı: Bu çalışma, Medipol Üniversitesi Klinik Araştırmalar Etik Kurulu tarafından 23 Haziran 2020 tarihinde onaylanmıştır (E- 10840098-604.01.01-6176). İki erkek hastaya çalışma hakkında sözlü ve yazılı bilgi verilerek katılımlarını düşünmeleri için yeterli zaman verilmiştir. Her iki gönüllü yazılı olarak onay vermiştir. Ayrıca, her iki katılımcı olası yayın hakkında bilgilendirilerek yayınlanma için yazılı onay alınmıştır.

\section{Hakem Değerlendirmesi: Dış bağımsız.}

Yazar Katkıları: Çalışma Konsepti/Tasarımı - A.A., S.B.K., I.K., A.K.; Veri Toplama - A.A., S.B.K., I.K., A.K.; Veri Analizi/Yorumlama - A.A., S.B.K., I.K., A.K.; Yazma - A.A., S.B.K., I.K., A.K.; Son Onay ve Sorumluluk - A.A., S.B.K., I.K., A.K.
Çıkar Çatışması: Yazarlar çıkar çatışması bildirmemişlerdir.

Finansal Destek: Çalışmamızın mali kısmı kendi bütçemizden sağlanmış ve Diagen Biyoteknolojik Sistemler tarafından desteklenmiştir.

\section{REFERENCES}

1. Gevers D, Knight R, Petrosino JF, Huang K, McGuire AL, Birren BW, et al. The Human Microbiome Project: A community resource for the healthy human microbiome. PLoS Biol 2012; 10(8): e1001377.

2. Blaser M, Bork P, Fraser C, Knight R, Wang J. The microbiome explored: recent insights and future challenges. Nat Rev Microbiol 2013; 11: 213-7. [CrossRef]

3. Alfano M, Ferrarese R, Locatelli I, Ventimiglia E, Ippolito S, Gallina $P$, et al. Testicular microbiome in azoospermic men: first evidence of the impact of an altered microenvironment. Hum Reprod 2018; 33: 1212-7. [CrossRef]

4. Markle JG, Frank DN, Mortin-Toth S, Robertson CE, Feazel LM, Rolle-Kampczyk U, et al. Sex differences in the gut microbiome drive hormone-dependent regulation of autoimmunity. Science 2013; 339: 1084-8. [CrossRef]

5. Magoc T, Salzberg SL. FLASH: fast length adjustment of short reads to improve genome assemblies. Bioinformatics 2011; 27: 2957-63. [CrossRef]

6. Caporaso JG, Lauber CL, Walters WA, Berg-Lyons D, Huntley J, Fierer $\mathrm{N}$, et al. Ultra-high-throughput microbial community analysis on the Illumina HiSeq and MiSeq platforms. ISME J 2012; 6(8): 1621-4. [CrossRef]

7. Barazani Y, Katz BF, Nagler HM, Stember DS. Lifestyle, environment, and male reproductive health. Urol Clin North Am 2014; 41: 55-66. [CrossRef]

8. Vogl AW, Soucy LJ, Foo V. Ultrastructure of Sertoli-cell penetrating processes found in germ cells of the golden-mantled ground squirrel (spermophilus lateralis). Am J Anat 1985; 172: 75-86. [CrossRef]

9. Hai Y, Hou J, Liu Y, Liu Y, Yang H, Li Z, et al. The roles and regulation of Sertoli cells in fate determinations of spermatogonial stem cells and spermatogenesis. Semin Cell Dev Biol 2014; 29: 66-75. [CrossRef]

10. Ryu BY, Orwig KE, Oatley JM, Avarbock MR, Brinster RL. Effects of aging and niche microenvironment on spermatogonial stem cell self-renewal. Stem Cells 2006; 24: 1505-11. [CrossRef]

11. Hou D, Zhou X, Zhong X, Settles ML, Herring J, Wang L, et al. Microbiota of the seminal fluid from healthy and infertile men. Fertil Steril 2013; 100: 1261-69. [CrossRef]

12. Weng SL, Chiu CM, Lin FM, Huang WC, Liang C, Yang T, et al. Bacterial communities in semen from men of infertile couples: metagenomic sequencing reveals relationships of seminal microbiota to semen quality. PLoS One 2014; 9: e110152. 